\title{
Dietary Protein Restriction and Preservation of Kidney Function in Chronic Kidney Disease
}

\author{
George A. Kaysen Golaun Odabaei \\ Division of Nephrology, Department of Medicine, University of California, Davis, Davis, Calif., USA
}

\section{Key Words}

Proteinuria · Renal acidification • Endothelin • Glomerular pressure

\begin{abstract}
Dietary protein augmentation elicits an increase in single nephron glomerular filtration rate (GFR) and increased transglomerular pressure. This is similar to the hemodynamic response to reduction in renal mass. Among patients and experimental animals with proteinuric renal disease, these changes also cause an increase in glomerular permselectivity, which in experimental animals accelerates loss of renal function. A meta-analysis of a group of prospective randomized trials including over 2,000 patients found a significant effect on reducing dietary protein decreasing the risk of endstage renal disease or death (defined as renal death). This differs somewhat in the outcomes of clinical trials using intermediate outcomes, such as the Modification of Diet in Renal Disease study that used change in GFR in part because of the initial hemodynamic effect of reduction in GFR mediated by dietary protein restriction. Copyright $\odot 2013$ S. Karger AG, Basel
\end{abstract}

\section{Introduction}

Despite several prospective controlled trials testing the efficacy of reduction in dietary protein, controversy still exists about the potential beneficial effect of reduction in dietary protein on the course and rate of progression of loss of renal function. Part of this controversy is related to the level of residual renal function that remained at the time of initiation of therapy, and part of the controversy is related to the heterogeneity of the populations tested, including some individuals with loss of renal function secondary to diseases that are unlikely to be affected by dietary protein restriction, most notably polycystic kidney disease [1]. An important issue with regard to establishing effectiveness is the endpoint chosen for study. The basis for this distinction is based upon the fact that one surrogate measure of glomerular filtration rate (GFR) is serum creatinine, a constituent of meat protein, so that dietary modulation may affect the creatinine level unrelated to changes in GFR, and a second, more important confounder, is that reduction in dietary protein will reduce GFR via well-studied hemodynamic mechanisms [2], as observed in the Modification of Diet in Renal Disease (MDRD) study [3].

\section{KARGER}

Fax +4161306 1234

E-Mail karger@karger.ch

www.karger.com
(C) 2013 S. Karger AG, Basel

$0253-5068 / 13 / 0353-0022 \$ 38.00 / 0$

Accessible online at:

www.karger.com/bpu
George A. Kaysen, MD, PhD

Department of Medicine, Division of Nephrology, University of California, Davis One Shields Ave, GBSF 451 E. Health Sciences Drive Davis, CA 95616 (USA)

E-Mail gakaysen@ucdavis.edu 
The physiologic response to dietary protein augmentation lays the foundation for expecting an effect on the rate of progression by increasing glomerular pressure compounding the effect of the physiologic response to reduction in nephron mass [2]. In addition, protein in the diet is accompanied by other constituents, most notably acid [4] that themselves likely lead to renal adaptation to loss of function that also causes renal injury. Finally, the effect of dietary protein to increase urinary protein loss among patients having renal diseases that are associated with glomerular proteinuria also provides a clear mechanism that should be anticipated to accelerate interstitial renal fibrosis and loss of GFR [5]. Since symptoms of uremia are associated with breakdown products of protein catabolism, restriction in dietary protein can delay the need to start renal replacement therapy despite a decline in GFR simply by ameliorating symptoms potentially introducing bias favoring dietary protein restriction independently of mechanisms protecting renal function directly. Two comprehensive meta-analyses have been published $[6,7]$.

\section{Mechanisms of Dietary Protein-Induced Renal Injury}

Dietary protein increases GFR acutely both in experimental animals [2] and in humans [8]. The mechanism is one of increased glomerular pressure and is similar to the adaptive response that occurs to compensate for the loss of renal mass $[2,8]$. The additive effect of both stimuli combine to cause glomerular hypertrophy and accelerate the loss of renal function once GFR has been reduced by disease or loss of renal mass $[9,10]$, although in otherwise healthy humans the loss of renal mass required to increase risk of progressive loss of glomerular function is greater than the loss of one kidney, unlike seen in rodent models of disease [2]. In the presence of proteinuria, increased dietary protein alters glomerular permselectivity [11], increasing urinary albumin loss [3, 4,12 ] and actually results in a decrease in serum albumin concentration among patients with the nephrotic syndrome [12]. Additionally, dietary protein also delivers an increased acid load per nephron providing a non-hemodynamic mechanism promoting renal injury through the induction of endothelin and aldosterone in response to increased nephron ammonia generation [4]. Alteration in the rate of decline in renal function in experimental animals having sustained partial renal ablation by alteration in the level of dietary protein can be clearly demonstrated [6].

Dietary Protein Restriction Preserves

Kidney Function in CKD

\section{Results of Clinical Trials}

Multiple clinical trials of varying sizes have been reported, and meta-analyses of randomized clinical trials show a clear benefit of protein restriction in reduction in the rate of loss of renal function in non-diabetic patients with regard to reducing the risk of development of endstage kidney disease when a hard endpoint of either death or the need for renal replacement therapy is used as the outcome (defined as renal death by the investigators) $[6,7]$. The study examined randomized prospective clinical trials enrolling a total of 2,000 subjects when subjects who consumed one of several low-protein diets $(0.3-0.6 \mathrm{~g} / \mathrm{kg})$ were compared to those having a higher protein intake ( $\geq 0.8 \mathrm{~g} / \mathrm{kg}$ ) [7]. This analysis combined the results of several randomized prospective studies and did not include retrospective or uncontrolled studies. While the MDRD study was the largest within this group including 585 subjects, the p value obtained in that trial was 0.07 [3], patients randomized to the low protein diet had a significantly slower rate of loss of GFR function after an initial decline that was likely hemodynamically mediated. Furthermore, the effectiveness of the MDRD study $[3,13]$ was primarily based upon rate of decline in GFR among those with stage III CKD, so the confounding hemodynamic effect of reduction in dietary protein that occurred in the initial period strongly biased the study to provide a negative outcome, despite the lower rate of loss of renal function following the initial decline that was most likely predictable and hemodynamically mediated.

The effect of very-low-protein diets supplemented either with essential amino acids or keto acid analogues on mortality outcomes has been controversial. Subgroup analyses of mortality among patients randomized to very low protein plus supplements have revealed either no difference in mortality following initiation of renal replacement therapy [14] or an increase in mortality compared to subjects randomized to low protein intake [15]. Subgroup analyses of the MDRD subjects found that those randomized to the low protein intake or very low protein intake both experienced a significant reduction in the rate of loss of renal function with a $0.2 \mathrm{~g} / \mathrm{kg} /$ day lower achieved total protein intake being associated with a 1.15 $\mathrm{ml} / \mathrm{min} /$ year slower mean decline in GFR $(\mathrm{p}=0.011)$ [13], despite the increased mortality risk in the follow-up period during which dietary protein intake was no longer controlled [15]. 


\section{Effect of Dietary Protein Restriction on Proteinuria}

Reduction in dietary protein intake has reduced proteinuria and glomerular permselectivity in patients having the nephrotic syndrome $[5,8,12]$. Proteinuria likely plays a role in progression of renal disease in which significant amounts of protein are filtered through tubular uptake of protein, complement activation [16], increased urinary excretion of monocyte chemoattractant protein-1, macrophage activation and interstitial and tubular fibrosis [17]. There was a significant association between both baseline proteinuria and the decrease in urinary protein excretion effected by reduction in blood pressure on the protective effect of low-protein diets in the MDRD cohort [18], although an effect of reduction in dietary protein was not statistically significant.

Use of soy proteins in place of animal proteins has also been shown to have efficacy in reduction in urinary protein losses [19]. In studies in experimental animals the rate of loss of renal function is greater in rats maintained on a casein-based diet compared to soy [4]. This effect is likely mediated by the differences in acid load associated with the two sources of protein sources, although differences in amino acid composition may contribute. We had observed that the effect of increasing dietary amino acid content on urinary protein excretion in nephrotic rats was dependent upon amino acid composition and not total amino acid load $[19,20]$, although the acid content of these diets was not controlled.

The use of pharmacologic agents that affect the activity of the renin-angiotensin-aldosterone axis has proved effective in reduction of proteinuria and protection of renal function, especially among patients having proteinuria $[22,23]$ or with diabetes [24]. Although dietary protein augmentation works at least in part through activation of these systems, the addition of protein restriction to pharmacologic blockade of this system has proved beneficial in the reduction of urinary protein loss both in experimental renal disease [25] and in humans [26], suggesting that dietary protein restriction may play a beneficial role that is not replaced by pharmacologic intervention alone.

\section{Conclusion}

Protein restriction has been found to be effective in reducing the rate of loss of renal function in patients with type 1 diabetes [27], a pathologic condition that would be anticipated to have an exaggerated effect of glomerular hyperfiltration in development of renal injury, thus potentially potentiating the effect of greater protein intake.

There is general agreement on the effect of dietary protein restriction on urinary protein losses and on reducing the rate of loss of GFR among most forms of renal injury in humans $[3,6,13,28]$. There are several potentially injurious pathways that have been well established whereby diets containing high levels of protein should facilitate renal injury $[2,4,8,11]$. What remains controversial is the magnitude of the effect $[6,7,28]$. Establishment of outcomes that utilize changes in creatinine is potentially confounded by creatinine that is introduced into the diet by some sources of dietary proteins confounding the use of this analyte as a surrogate of renal function. This problem is overcome by direct measurements of GFR by use of iothalamate or inulin clearance; however, since dietary protein directly and quickly affects GFR hemodynamically [8], the initial decline in GFR that was clearly demonstrated in the first 4 months of the MDRD study [3] also confounds outcomes based upon changes in GFR throughout a defined study period. A sharper and more definitive outcome is death or the need for renal replacement therapy (either dialysis or transplantation) any time during or following the study, although the delay of dialysis resulting from decreased symptoms of azotemia that are effected by reduction in urea nitrogen generation may introduce bias favoring protein restriction that has nothing to do with preservation of renal function. In a comparison of ten clinical trials in which a total of 2,000 patients were enrolled, the risk of renal death among patients with stage III CKD consuming either a protein intake of 0.6 versus $1.1 \mathrm{~g} / \mathrm{kg} /$ day was 0.68 (range $0.55-0.84$ ) $(p<0.001)$ [7]. When loss of GFR was used in a metaanalysis using many of the same studies with a similar number of subjects $(1,919)$, while it was clear that protein restriction was effective, the effect size was quite small, namely $0.53 \mathrm{ml} / \mathrm{min} /$ year (range 0.08-0.98) [28]. Neither of the analyses included diabetics and neither identified proteinuria as a predictor of effectiveness of dietary protein restriction. The principal differences between the studies is the length of follow-up and use of hard clinical outcomes rather than rate of loss of renal function, as suggested previously [18]. 


\section{References}

$>1$ Klahr S, Breyer JA, Beck GJ, Dennis VW, 11 Nath KA, Kren SM, Hostetter TH: Dietary Hartman JA, Roth D, Steinman TI, Wang SR, Yamamoto ME: Dietary protein restriction, blood pressure control, and the progression of polycystic kidney disease. Modification of Diet in Renal Disease Study Group. J Am Soc Nephrol 1995;5:2037-2047.

-2 Brenner BM: Nephron adaptation to renal injury or ablation. Am J Physiol 1985; 249:F324-F337.

3 Klahr S, Levey AS, Beck GJ, Caggiula AW, Hunsicker L, Kusek JW, Striker G: The effects of dietary protein restriction and bloodpressure control on the progression of chronic renal disease. Modification of Diet in Renal Disease Study Group. N Engl J Med 1994;330:877-884.

$\checkmark 4$ Wesson DE, Simoni J: Increased tissue acid mediates a progressive decline in the glomerular filtration rate of animals with reduced nephron mass. Kidney Int 2009;75:929-935.

$\checkmark 5$ Rosenberg ME, Swanson JE, Thomas BL, Hostetter TH: Glomerular and hormonal responses to dietary protein intake in human renal disease. Am J Physiol 1987;253:F1083F1090.

6 Fouque D, Wang P, Laville M, Boissel JP: Low protein diets for chronic renal failure in nondiabetic adults. Cochrane Database Syst Rev 2001;CD001892. Update in: Cochrane Database Syst Rev 2006;CD001892.

7 Fouque D, Laville M: Low protein diets for chronic kidney disease in non diabetic adults. Cochrane Database Syst Rev 2009; 8:CD001892.

-8 Brenner BM, Meyer TW, Hostetter TH: Dietary protein intake and the progressive nature of kidney disease: the role of hemodynamically mediated glomerular injury in the pathogenesis of progressive glomerular sclerosis in aging, renal ablation, and intrinsic renal disease. N Engl J Med 1982;307:652659.

$>9$ Novick AC, Gephardt G, Guz B, Steinmuller D, Tubbs RR: Long-term follow-up after partial removal of a solitary kidney. N Engl J Med 1991;325:1058-1062.

-10 Lau WK, Blute ML, Weaver AL, Torres VE, Zincke H: Matched comparison of radical nephrectomy vs. nephron-sparing surgery in patients with unilateral renal cell carcinoma and a normal contralateral kidney. Mayo Clin Proc 2000;75:1236-1242. protein restriction in established renal injury in the rat. Selective role of glomerular capillary pressure in progressive glomerular dysfunction. J Clin Invest 1986;78:11991205.

12 Kaysen GA, Gambertoglio J, Jimenez I, Jones $\mathrm{H}$, Hutchison FN: Effect of dietary protein intake on albumin homeostasis in nephrotic patients. Kidney Int 1986;29:572-577.

13 Levey AS, Adler S, Caggiula AW, England BK, Greene T, Hunsicker LG, Kusek JW, Rogers NL, Teschan PE: Effects of dietary protein restriction on the progression of advanced renal disease in the Modification of Diet in Renal Disease study. Am J Kidney Dis 1996;27:652-663.

14 Aparicio M, Chauveau P, De Précigout V, Bouchet JL, Lasseur C, Combe C: Nutrition and outcome on renal replacement therapy of patients with chronic renal failure treated by a supplemented very low protein diet. J Am Soc Nephrol 2000;11:708-716.

15 Menon V, Kopple JD, Wang X, Beck GJ, Collins AJ, Kusek JW, Greene T, Levey AS, Sarnak MJ: Effect of a very low-protein diet on outcomes: long-term follow-up of the Modification of Diet in Renal Disease (MDRD) study. Am J Kidney Dis 2009;53:208-217.

16 Abbate M, Zoja C, Rottoli D, Corna D, Perico N, Bertani T, Remuzzi G: Antiproteinuric therapy while preventing the abnormal protein traffic in proximal tubule abrogates protein- and complement-dependent interstitial inflammation in experimental renal disease. J Am Soc Nephrol 1999;10:804813.

17 Eardley KS, Zehnder D, Quinkler M, Lepenies J, Bates RL, Savage CO, Howie AJ, Adu D, Cockwell P: The relationship between albuminuria, MCP-1/CCL2, and interstitial macrophages in chronic kidney disease. Kidney Int 2006;69:1189-1197.

8 Levey AS, Greene T, Beck GJ, Caggiula AW, Kusek JW, Hunsicker LG, Klahr S: Dietary protein restriction and the progression of chronic renal disease: what have all of the results of the MDRD study shown? Modification of Diet in Renal Disease Study Group. J Am Soc Nephrol 1999;10:2426-2439.

-19 D’Amico G, Gentile MG, Manna G, Fellin G, Ciceri R, Cofano F, Petrini C, Lavarda F, Perolini S, Porrini M: Effect of vegetarian soy diet on hyperlipidaemia in nephrotic syndrome. Lancet 1992;339:1131-1134.
20 Kaysen GA, Martin VI, Jones H Jr: Arginine augments neither albuminuria nor albumin synthesis caused by high-protein diets in nephrosis. Am J Physiol 1992;263:F907-F914.

21 Kaysen GA, al-Bander H, Martin VI, Jones H Jr, Hutchison FN: Branched-chain amino acids augment neither albuminuria nor albumin synthesis in nephrotic rats. Am J Physiol 1991;260:R177-R184.

22 The GISEN Group (Gruppo Italiano di Studi Epidemiologici in Nefrologia): Randomised placebo-controlled trial of effect of ramipril on decline in glomerular filtration rate and risk of terminal renal failure in proteinuric, non-diabetic nephropathy. Lancet 1997;349: 1857-1863.

-23 Eijkelkamp WB, Zhang Z, Remuzzi G, Parving $\mathrm{HH}$, Cooper ME, Keane WF, Shahinfar S, Gleim GW, Weir MR, Brenner BM, de Zeeuw D: Albuminuria is a target for renoprotective therapy independent from blood pressure in patients with type 2 diabetic nephropathy: post hoc analysis from the Reduction of Endpoints in NIDDM with the Angiotensin II Antagonist Losartan (RENAAL) trial. J Am Soc Nephrol 2007;18: 1540-1546.

24 Brenner BM, Cooper ME, de Zeeuw D, Keane WF, Mitch WE, Parving $\mathrm{HH}, \mathrm{Re}$ muzzi G, Snapinn SM, Zhang Z, Shahinfar S; RENAAL Study Investigators: Effects of losartan on renal and cardiovascular outcomes in patients with type 2 diabetes and nephropathy. N Engl J Med 2001;345:861869.

25 Hutchison FN, Martin VI, Jones H Jr, Kaysen GA: Differing actions of dietary protein and enalapril on renal function and proteinuria Am J Physiol Renal Physiol 1990;258:F126F132.

26 Gansevoort RT, de Zeeuw D, de Jong PE: Additive antiproteinuric effect of ACE inhibition and a low-protein diet, in human renal disease. Nephrol Dial Transplant 1995;10: 497-504.

27 Zeller K, Whittaker E, Sullivan L, Raskin P, Jacobson HR: Effect of restricting dietary protein on the progression of renal failure in patients with insulin-dependent diabetes mellitus. N Engl J Med 1991;324:78-84.

28 Kasiske BL, Lakatua JD, Ma JZ, Louis TA: A meta-analysis of the effects of dietary protein restriction on the rate of decline in renal function. Am J Kidney Dis 1998;31:954-961. 